Original Research Article

\title{
Evaluation of opioid sparing effect of dexmedetomidine and pregabalin using acute pain model in male wistar rats
}

\author{
Sudar Codi R.*, Sumina, Uma N., Manimekalai K.
}

Department of Pharmacology, Mahatma Gandhi Medical College and Research Institute, Sri Balaji Vidyapeeth, Deemed to be University, Puducherry, India

Received: 14 June 2019

Revised: 30 June 2019

Accepted: 06 July 2019

*Correspondence to:

Dr. Sudar Codi R.,

Email: sudarcodi@gmail.com

Copyright: (C) the author(s), publisher and licensee Medip Academy. This is an openaccess article distributed under the terms of the Creative Commons Attribution NonCommercial License, which permits unrestricted noncommercial use, distribution, and reproduction in any medium, provided the original work is properly cited.

\begin{abstract}
Background: Adjuvant analgesics are added to pain management regimen to reduce opioid consumption and minimise their side effect. Newer ones like dexmedetomidine and pregabalin have not been thoroughly researched. Objectives of the study to study the opioid sparing effect of dexmedetomidine and pregabalin using tail flick and hot plate method in male wistar rats.

Methods: Forty two rats were grouped into seven groups with six in each group. Analgesic activity was tested using tail flick, where in the reaction time to flick its tail on a heated surface was noted. In the hot plate method, the reaction time to withdraw or lick the paws when placed on heated surface was noted.

Results: The reaction time to flick its tail was prolonged with dexmedetomidine and pregabalin when combined with opioids even in sub therapeutic doses.

Conclusion: Adjuncts like dexmedetomidine and pregabalin can be very useful in mutimodal pain management and also to reduce the opioid consumption.
\end{abstract}

Key words: Dexmedetomidine, Hot plate method, Pregabalin, Tail flick method

\section{INTRODUCTION}

Multimodal Analgesia in pain management is a rapidly upcoming treatment modality that aims to combine different analgesics that act by different mechanisms at different sites in the nervous system to provide synergistic effect, reduce the opioid consumption and lower the adverse effects of opioid analgesics. ${ }^{1}$

Opioids are the mainstay analgesics in pain management that produce undesirable adverse effects like respiratory depression, vomiting, mucle rigidity, acute tolerance and hyperalgesia. Hence adjuvant analgesics are added to reduce opioid consumption, commonly referred as "opioid sparing" effect. ${ }^{2,3}$ Dexmedetomidine is a $\alpha_{2}$ agonist approved by FDA as a sedative analgesic drug in intensive care unit, with very minimal respiratory depression and also reduces opioid tolerance. ${ }^{4}$ Pregabalin is a structural derivative of gamma amino butyric acid that has analgesic, anticonvulsant and anxiolytic properties and used as an adjunct analgesic. ${ }^{5}$

The analgesic effect of dexmedetomodine has not been extensively studied as it is an recently introduced drug. 
Moreover, dexmedetomidine and pregabalin can be used along with opioids to reduce their consumption and thereby side effects.

Hence we planned to study the opioid sparing effect of dexmedetomidine and pregabalin using tail flick and hot plate method in male wistar rats.

\section{METHODS}

After approval from the institutional animal ethics committee, 42 adult male Wistar rats were procured from TANVAS institute, Chennai and were housed in Central Animal House, Mahatma Gandhi Medical College and Research Institute, Pondicherry. As per the CPCSEA guidelines, the rats were housed 3 per cage with adequate bedding material and adequate social interaction were allowed.

The rats were allowed to acclimatize to the laboratory environment for a period of 1 week with alternate light dark cycle at room temperature of $22+2^{\circ} \mathrm{C}$ providing free access to food (pellet chow diet) and water ad libitum. There will be 7 groups with 6 rats in each group.

- Group I: Normal saline at dose of $10 \mathrm{ml} / \mathrm{kg}$

- Group II: Fentanyl under trade name of Trofentyl procured from Troika pharmaceuticals(100 $\mathrm{mcg} / 2 \mathrm{ml}$ ); at a dose of $30 \mathrm{mcg} / \mathrm{kg}$

- Group III: Fentanyl under trade name of Trofentyl procured from Troika pharmaceuticals (100 $\mathrm{mcg} / 2 \mathrm{ml}$ ); at a dose of $15 \mathrm{mcg} / \mathrm{kg}$

- Group IV: Dexmedetomidine under trade name of Dextomid procured from Neon laboratories, Mumbai $(100 \mathrm{mcg} / / \mathrm{ml})$ at dose of $60 \mathrm{mcg} / \mathrm{kg}$

- Group V: Pregabalin under trade name of Preglan procured from Speciality Meditech Pvt Ltd $(10 \mathrm{mg} / \mathrm{ml})$ at dose of $30 \mathrm{mcg} / \mathrm{kg}$

- Group VI: Combination of Fentanyl $(15 \mathrm{mcg} / \mathrm{kg})$ and Dexmedetomidine $(30 \mathrm{mcg} / \mathrm{kg}$ )

- Group VII: Combination of Fentanyl $(15 \mathrm{mcg} / \mathrm{kg})$ and Pregabalin $(15 \mathrm{mcg} / \mathrm{kg})$

All the drugs were administered by intra peritoneal route. Dosages were chosen according to previous successful studies.

\section{Tail flick method}

The analgesic activity was tested by tail flick method, by radiant heat using analgesiometer, the standard method to test potency of centrally acting analgesic agents. ${ }^{6}$

The rat was placed in restrainer such that proximal third of tail was left behind. Radiant heat was delivered to proximal third of tail. After few seconds the rat was observed for flicking the tail. This reading was taken as the end point. This reaction time at which the rat flicks the tail was noted. Before giving the drug, the reaction time was noted as the baseline response. The drugs were administered according to the respective groups in respective dosages. Readings were taken at 30, 60, 90 and 120 minutes of giving the drug and the respective reaction times were noted.

\section{Hotplate method}

After a washout period of 15 days the rats were divided according to groups and the analgesic activity was tested by hotplate method. ${ }^{7}$ The rats were placed on the hot plate which consists of an electrically heated surface at a temperature of 55-56 degree. Responses such as jumping, withdrawal of paws and licking of paws were seen. The reaction time period until the responses occurs were noted. Drugs were administered and the time period to produce any of these response were noted at 30,60 and 90 and 120 minutes of administering the drug. All the observed data were recorded in Microsoft excel and statistical analysis was done using SPSS version 16 software.

\section{RESULTS}

The reaction times observed in estimating the analgesic effect using tail flick and hot plate method is tabulated in Tables 1 and 2. Mean SD was used to evaluate the mean value of the observations in each group. Opioid sparing effect of dexemedetomidine and pregabalin was analysed by ANOVA. $\mathrm{p}<0.05$ was considered to be statistically significant. The results of the study revealed that both dexmedetomidine and pregabalin had good analgesic effect and the opioid sparing effect of reducing the opioid consumption was higher in dexmedetomidine than pregabalin in both tail flick and hot plate methods.

\section{DISCUSSION}

Opioids are the mainstay of postoperative analgesia and chronic pain. Its use is limited by the occurrence of dose related side effects like respiratory depression, nausea, vomiting, sedation etc. Hence many analgesics. ${ }^{8}$ like clonidine, dexmedetomidine, steroids, diazepam are used as adjuncts in pain relief to overcome the limitations of opioids. In our study dexmedetomidine produced good analgesic effects even with less opioid dose revealing its opioid sparing effect. In our study, the reaction time period of dexmedetomidine $60 \mathrm{mcg} / \mathrm{kg}$ in tail flick method was $4.92 \pm 0.17 \mathrm{~min}$ at the end of 90 minutes of administering the drug. When Fentanyl $15 \mathrm{mcg} / \mathrm{kg}$ and Dexmedetomidine $30 \mathrm{mcg} / \mathrm{kg}$ was administered to the rats, the reaction time was $4.80 \pm 0.22$ minutes. Similar results were obtained in hot plate method also. This reveals that dexmedetomidine in sub therapeutic doses when combined with opioids produce good analgesic effect, thereby therapeutically useful as a analgesic adjunct in pain management. Also, it reduced the opioid consumption which is very useful in limiting the side effects of opioids like respiratory depression and tolerance leading to addiction when used chronically. 
Table 1: Reaction time observed in tail flick method.

\begin{tabular}{|lllllll|}
\hline Groups & Drug dosage & $\begin{array}{l}\text { Reaction time in minutes observed } \\
\text { Before the } \\
\text { drug }\end{array}$ & $\begin{array}{l}\text { 30 mins } \\
\text { after drug }\end{array}$ & $\begin{array}{l}\text { 60 mins } \\
\text { after drug }\end{array}$ & $\begin{array}{l}\text { 90 mins } \\
\text { after drug }\end{array}$ & $\begin{array}{l}\mathbf{1 2 0} \text { mins } \\
\text { after drug }\end{array}$ \\
\hline I & Normal saline & $0.76 \pm 0.02$ & $0.76 \pm 0.02$ & $0.78 \pm 0.01$ & $0.78 \pm 0.02$ & $0.77 \pm 0.29$ \\
\hline II & Fentanyl $30 \mathrm{mcg} / \mathrm{kg}$ & $0.78 \pm 0.09$ & $2.10 \pm 0.36$ & $3.02 \pm 0.40$ & $4.02 \pm 0.33$ & $4.01 \pm 0.22$ \\
\hline III & Fentanyl $15 \mathrm{mcg} / \mathrm{kg}$ & $0.80 \pm 0.02$ & $2.90 \pm 0.25$ & $3.20 \pm 0.29$ & $4.94 \pm 0.23$ & $4.98 \pm 0.24$ \\
\hline IV & Dexmedetomidine $60 \mathrm{mcg} / \mathrm{kg}$ & $0.82 \pm 0.01$ & $3.06 \pm 0.18$ & $4.59 \pm 0.10$ & $4.92 \pm 0.17$ & $4.38 \pm 0.22$ \\
\hline V & Pregabalin $30 \mathrm{mcg} / \mathrm{kg}$ & $0.74 \pm 0.03$ & $0.74 \pm 0.08$ & $0.78 \pm 0.09$ & $1.92 \pm 0.86$ & $2.80 \pm 0.25$ \\
\hline VI & $\begin{array}{l}\text { Fentanyl } 15 \mathrm{mcg} / \mathrm{kg} \mathrm{and} \\
\text { Dexmedetomidine } 30 \mathrm{mcg} / \mathrm{kg}\end{array}$ & $0.76 \pm 0.03$ & $3.10 \pm 0.06$ & $4.80 \pm 0.22$ & $5.05 \pm 0.28$ & $4.89 \pm 0.25$ \\
\hline VII & $\begin{array}{l}\text { Fentanyl } 15 \mathrm{mcg} / \mathrm{kg} \text { with } \\
\text { Pregabalin } 15 \mathrm{mcg} / \mathrm{kg}\end{array}$ & $0.84 \pm 0.03$ & $1.08 \pm 0.18$ & $2.76 \pm 0.25$ & $3.22 \pm 0.98$ & $3.40 \pm 0.62$ \\
\hline
\end{tabular}

Comparison of groups 1,2,3,4,6: $\mathrm{df}=1, \mathrm{~F}=2.51, \mathrm{p}=0.000$.*** Comparison of groups $1,2,3,5,7 \mathrm{df}=1, \mathrm{~F}=1.48, \mathrm{p}=0.000 * *$

Table 2: Reaction time observed in Hot plate Method.

\begin{tabular}{|lllllll|}
\hline Groups & Drug dosage & $\begin{array}{l}\text { Reaction time in minutes observed } \\
\text { Before the }\end{array}$ & $\begin{array}{l}\mathbf{3 0} \text { mins } \\
\text { drug }\end{array}$ & $\begin{array}{l}\mathbf{6 0} \text { mins } \\
\text { after drug }\end{array}$ & $\begin{array}{l}\mathbf{9 0} \text { mins } \\
\text { after drug }\end{array}$ & $\begin{array}{l}\mathbf{1 2 0} \text { mins } \\
\text { after drug }\end{array}$ \\
\hline I & Normal saline & $3.96 \pm 0.52$ & $2.89 \pm 0.16$ & $3.92 \pm 0.30$ & $3.24 \pm 0.03$ & $3.22 \pm 0.14$ \\
\hline II & Fentanyl $30 \mathrm{mcg} / \mathrm{kg}$ & $3.18 \pm 0.02$ & $6.66 \pm 0.02$ & $6.92 \pm 0.03$ & $6.83 \pm 0.09$ & $6.10 \pm 0.02$ \\
\hline III & Fentanyl $15 \mathrm{mcg} / \mathrm{kg}$ & $3.32 \pm 0.08$ & $6.68 \pm 0.07$ & $7.86 \pm 0.23$ & $8.24 \pm 0.30$ & $7.50 \pm 0.03$ \\
\hline IV & $\begin{array}{l}\text { Dexmedetomidine } 60 \\
\text { mcg/kg }\end{array}$ & $3.40 \pm 0.04$ & $7.78 \pm 0.18$ & $8.18 \pm 0.26$ & $8.55 \pm 0.07$ & $8.11 \pm 0.23$ \\
\hline V & Pregabalin $30 \mathrm{mcg} / \mathrm{kg}$ & $3.33 \pm 0.05$ & $3.86 \pm 0.29$ & $3.66 \pm 0.27$ & $3.67 \pm 0.04$ & $3.40 \pm 0.14$ \\
\hline VI & $\begin{array}{l}\text { Fentanyl } 15 \mathrm{mcg} / \mathrm{kg} \\
\text { and Dexmedetomidine } \\
\text { and 30 mcg/kg }\end{array}$ & $3.22 \pm 0.04$ & $7.41 \pm 0.27$ & $8.22 \pm 0.23$ & $8.66 \pm 0.30$ & $8.19 \pm 0.30$ \\
\hline VII & $\begin{array}{l}\text { Fentanyl 15 mcg/kg } \\
\text { with Pregabalin } 15\end{array}$ & $3.20 \pm 0.60$ & $6.19 \pm 0.22$ & $6.72 \pm 0.10$ & $6.15 \pm 0.70$ & $5.85 \pm 0.09$ \\
\hline
\end{tabular}

Comparison of groups $1,2,3,4,6: \mathrm{df}=1, \mathrm{~F}=8.07, \mathrm{p}=0.000 * * *$. Comparison of groups $1,2,3,5,7: \mathrm{df}=1, \mathrm{~F}=863.678, \mathrm{p}=0.000 * *$

Similar study by Mumin unal et al. who evaluated the synergistic potentiation effect of ineffective doses of dexmedetomidine on antinociception induced by morphine and fentanyl in acute pain model in rats reported that the analgesic effect of dexmedetomidine with morphine and dexmedetomidine with fentanyl, was significantly higher at $15,30,60$ and 90 minutes after administration of the drug than either drug alone. ${ }^{9}$

This effect, thereby the opioid sparing effect of dexmedetomidine is attributed to $\alpha 2$ adrenegic agonistic action of dexmedetomidine on the presynaptic receptors thereby inhibiting the release of substance P. These receptors are abundant at the locus cereleus thereby responsible for the analgesic effect. The inhibition of substance $\mathrm{P}$ would be the the probable reason supporting the reduction of opioid requirements by dexmedetomidine. ${ }^{10}$

Neusa Maria et al, performed a study on the opioid consumption in total intravenous anesthesia(TIVA) in patients undergoing gynecologic video laparoscopic surgery and reported that dexmedetomidine is a very efficient drug in TIVA and opioid consumption is reduced. Moreover, in our study the reaction time period of Pregabalin $15 \mathrm{mcg} / \mathrm{kg}$ with Fentanyl $15 \mathrm{mcg} / \mathrm{kg}$ in tail flick method was $3.22 \pm 0.98 \mathrm{~min}$ at the end of 90 minutes of administering the drug. Similar results were obtained in hot plate method also. Unlike dexmedetomidine, this result was higher than pregabalin alone but not with standard drug fentanyl alone which reveals the weak analgesic effect and can be used as a potential analgesic adjunct in chronic pain, post-operative pain etc. ${ }^{11}$

Clendensen et al, performed a study on 50 patients undergoing rotator cuff repair and pregabalin $50 \mathrm{mg}$ was prescribed orally twice a day. He observed that the mean opioid consumption was reduced when combined with pregabalin and he reported pregabalin to be a very useful adjunct in pain management. ${ }^{12}$ This opioid sparing effect of pregabalin is probably due the reduction in the release of substance $\mathrm{P}$ by tight binding to the $\alpha 2$ subunit of calcium channels. ${ }^{13}$ The credentials of this study will be validated only when performed in humans which is the major 
limitation. Our study adds on to the information available to help the clinicians make a healthy decision.

\section{CONCLUSION}

As revealed by authors of the study, adjuncts like dexmedetomidine and pregabalin can be very useful in multimodal pain management and also to reduce the opioid consumption.

Funding: No funding sources Conflict of interest: None declared

Ethical approval: The study was approved by the Institutional Ethics Committee

\section{REFERENCES}

1. White PF. The changing role of non-opioid analgesic techniques in the management of postoperative pain. Anesthesia and Analgesia 2005Nov;101:S5-22.

2. Jong RD, Shrysh AJ. Development of a Multimodal Analgesia Protocol for Perioperative Acute Pain Management for Lower Limb Amputation. Pain Res Manag. 2018;2018:1-9.

3. Aho MS, Erkola OA, Scheinin H, Lehtinen AM, Korttila KT. Effect of intravenously administered dexmedetomidine on pain after laparoscopic tubal ligation. Anesth Analg. 1991;73:112-8.

4. Bhana N, Goa KL, McClellan KJ. Dexmedetomidine. Drugs. 2000;59:263-70.

5. Gajraj NM. Pregabalin: Its Pharmacology and Use in Pain Management. Anaes Analg. 2007;105(6):180515.

6. Deuis JR, Dvorakova LS, Vetter I. Methods Used to Evaluate Pain Behaviours in Rodents. Frontiers Molecular Neurosci. 2017;10:1-15.
7. Parle M, Yadav M. Laboratory models for screening analgesics. Int Res J Pharmacy. 2013;4(1):15-19.

8. Habib HS, Gan TJ. Role of analgesic adjuncts in PostOperative Pain Management. Anaesthesiol Clin N Am. 2005;23:85-107.

9. Unal M, Gursoy S, Altun A, Duger C, Kol IO, Kaygusuz $\mathrm{K}$, et al. Ineffective doses of dexmedetomidine potentiates the antinociception induced by morphine and fentanyl in acute pain model. Korean J Physiol Pharmacol. 2013;17(5):417-22.

10. Gurosy S, Ozdemir E, Bagcivan I, Altun A, Durmus N. Effect of alpha 2-adrenoreceptor agonists dexmedetomidine and guanfacine on morphine analgesia and tolerance in rats. Upsala J Med Scien. 2011;116:238-46.

11. Bulow NM, Barbosa NV, Rocha JB. Opioid consumption in total intravenous anesthesia is reduced with dexmedetomidine: a comparative study with remifentanil in gynecologic videolaparoscopic surgery. J Clinical Anesthesia. 2007;19(4):280-5.

12. Clendenen SR, Rajendran S, Kopacz DJ, Greengrass $\mathrm{R}$, Robards C, Weinstein D, et al. Logvinov II. Pregabalin as an adjunct to a multimodal analgesic regimen to achieve opioid sparing in arthroscopic rotator cuff repair. Jurnalul Roman de Anestezie Terapie Intensiva/Romanian J Anaesth Intensive Care. 2010 Apr;17:5-10.

13. Gajraj NM. Pregabalin for pain management. Pain Pract. 2005 Jun;5:95-102.

Cite this article as: Codi SR, Sumina, Uma N, Manimekalai K. Evaluation of opioid sparing effect of dexmedetomidine and pregabalin using acute pain model in male wistar rats. Int J Basic Clin Pharmacol 2019;8:1911-4. 